University of Nebraska - Lincoln

DigitalCommons@University of Nebraska - Lincoln

USDA National Wildlife Research Center - Staff Publications
U.S. Department of Agriculture: Animal and Plant Health Inspection Service

February 2006

\title{
What carnivore biologists can learn from bugs, birds, and beavers: a review of spatial theories
}

Julie K. Young

Utah State University, Logan, julie.k.young@aphis.usda.gov

John A. Shivik

Utah State University, Logan, UT

Follow this and additional works at: https://digitalcommons.unl.edu/icwdm_usdanwrc

Part of the Environmental Sciences Commons

Young, Julie K. and Shivik, John A., "What carnivore biologists can learn from bugs, birds, and beavers: a review of spatial theories" (2006). USDA National Wildlife Research Center - Staff Publications. 452.

https://digitalcommons.unl.edu/icwdm_usdanwrc/452

This Article is brought to you for free and open access by the U.S. Department of Agriculture: Animal and Plant Health Inspection Service at DigitalCommons@University of Nebraska - Lincoln. It has been accepted for inclusion in USDA National Wildlife Research Center - Staff Publications by an authorized administrator of DigitalCommons@University of Nebraska - Lincoln. 


\title{
What carnivore biologists can learn from bugs, birds, and beavers: a review of spatial theories
}

\author{
Julie K. Young and John A. Shivik
}

\begin{abstract}
Information on the ecology and evolution of a species can be enhanced by studying spatial ecology. Even though space use has been a focus of carnivore research for decades, the theoretical framework for such studies remains poorly developed. Most spatial ecology theory has instead been developed and tested with invertebrates and expanded into fishery and ornithological research. The goal of this review is to examine spatial theories being tested in other taxonomic groups that could positively influence how carnivore biologists design studies. Details are provided from studies that illustrate methods to quantify space use, and four broad areas of spatial theory are reviewed: conspecific attraction, territory establishment, within-territory space use, and inheritance of space use. Suggestions are given on how carnivore biologists could incorporate each of these components into study designs. Carnivore biologists have opportunities to test spatial theory at small and large scales that could ultimately advance the entire field of spatial ecology. Although this review focuses on improving studies of terrestrial carnivores, our suggestions are relevant for studies of spatial theories across taxa.

Résumé : L'étude de l'écologie spatiale peut enrichir l'information que l'on possède sur l'écologie et l'évolution d'une espèce. Bien que l'utilisation de l'espace ait été un sujet d'étude important de la recherche sur les carnivores depuis des décennies, le cadre théorique pour ces études reste mal défini. La plupart des théories relatives à l'écologie spatiale ont plutôt été mises au point et vérifiées chez les invertébrés et ont été appliquées ensuite aux recherches sur les poissons et les oiseaux. Le but de notre rétrospective est d'examiner les théories qui sont testées dans les divers groupes taxonomiques et qui pourraient influencer de façon positive l'élaboration de plans de recherche par les biologistes intéressés aux carnivores. Nous fournissons des détails tirés d'études qui illustrent les méthodes pour mesurer l'utilisation de l'espace dans le cadre de quatre grands domaines théoriques de l'utilisation de l'espace: l'attirance entre individus de même espèce, l'établissement des territoires, l'utilisation de l'espace à l'intérieur d'un territoire et l'hérédité de l'utilisation de l'espace. Nous faisons des suggestions pour l'incorporation de chacune de ces composantes dans des plans d'études par les biologistes travaillant sur les carnivores. Les biologistes intéressés aux carnivores ont des occasions de tester la théorie spatiale à des échelles petites et grandes, ce qui pourrait en fin de compte faire avancer le domaine entier de l'écologie spatiale. Bien que notre rétrospective vise à améliorer les études sur les carnivores terrestres, nos suggestions s'appliquent à l'étude des théories spatiales chez tous les taxons.
\end{abstract}

[Traduit par la Rédaction]

\section{Introduction}

Information about animal space use can add significant value to studies of the ecology and evolution of a species. Detailed information about space use patterns can help researchers understand why animals prefer specific habitat patches, how animals utilize different areas, and what ecological variables influence populations. For example, researchers have found that livestock predation by carnivores is often patchily distributed (Stahl et al. 2002; Treves et al.
2004), and there are several potential explanations that could be tested with spatially explicit research methods. Woodroffe and Frank (2005) applied a spatially explicit approach to determine what factors resulted in African lions (Panthera leo) killing more livestock in one patch (i.e., ranch) than in others. By determining why some patches experience more predation, better plans to reduce livestock predation within those patches can be developed.

Although spatial approaches to ecological theory have advanced since space was first recognized as the final ecologi-

Received 27 June 2006. Accepted 25 October 2006. Published on the NRC Research Press Web site at http://cjz.nrc.ca on 22 December 2006.

J.K. Young. ${ }^{1,2}$ Department of Forest, Range, and Wildlife Sciences, Utah State University, Logan, UT 84322, USA.

J.A. Shivik. USDA - Wildlife Services - National Wildlife Research Center and Department of Forest, Range, and Wildlife Sciences,

Utah State University, Logan, UT 84322, USA.

${ }^{1}$ Corresponding author (e-mail: Julie.K.Young@asu.edu).

${ }^{2}$ Present address: Ecology, Evolution, and Environmental Sciences, School of Life Sciences, Arizona State University, Tempe, AZ 85287-1501, USA. 
cal frontier (Kareiva 1994), most advancements have been restricted to models or select taxonomic groups and few have been applied across multiple fields. Specifically, empirical tests of most spatial ecology theory have been developed with invertebrates and expanded into fishery and ornithological research, but there have been few attempts to apply spatial theory to other organisms, especially large mammalian carnivores (Table 1). Not all theories developed in other taxonomic groups are relevant to carnivores, but studies testing some theories could considerably advance the field, enhance our understanding of carnivore spatial ecology, and facilitate carnivore management and conservation.

Even though space use has been a focus of terrestrial research for decades (White and Garrott 1990), the theoretical framework for such studies remains poorly developed. Previous logistical limitations may have prevented scientists from applying theoretical exploration to empirical studies of terrestrial species such as large carnivores. Historically, studies used localized observational techniques to determine movement patterns (e.g., Sale 1975). The advent of radiotelemetry allowed researchers to obtain spatially explicit data on wide-ranging animals and on a variety of species that were difficult to observe directly (e.g., birds (Cochran et al. 1967), marine mammals (Gaskin et al. 1975), turtles (Bertram 1979), snakes (Speake and McGlincy 1981), and terrestrial carnivores (Buck et al. 1979)). Most of the techniques still used to analyze spatial data, such as home-range estimators, were developed during this era. Now that global positioning system (GPS) collars are reliable for many carnivore species, the technology used to collect data on animal movement has surpassed our ability to analyze it. Extensive and detailed movement data are now attainable, but most studies evaluate only a portion of the data (Claussen et al. 1997). We must move beyond the "collar-them-followthem" research approach and design carnivore studies based on theory, because successful management and conservation applications will emerge only through sound theoretical approaches. Our goal should be to develop a theoretical framework that improves our understanding and, ultimately, our management and conservation of carnivores.

Spatial phenomena that have been investigated in other taxonomic groups include territory establishment processes (Maynard Smith and Price 1973; Stamps and Krishnan 1997), the cost of neighbors (Getty 1987; Eason and Switzer 2004), resource dispersion (Macdonald 1983), conspecific attraction (Stamps 1988), territory inheritance (Lindström 1986), outbreak theories of invasion (Korniss and Caraco 2005), diffusion models of movement patterns (Skellam 1951), and natal habitat preference induction (NHPI; Davis and Stamps 2004). Like most of these examples, the NHPI hypothesis had been developed with invertebrates, tested in numerous invertebrate species, and advanced through studies of several species of fish, amphibians, and birds (Davis and Stamps 2004). Although NHPI may seem difficult to study in carnivores because they are typically long-lived species that disperse far from their natal habitat, NHPI was successfully tested in carnivores via genetic analysis (Sacks et al. 2004,2005 ). While methods to quantify space use, such as correlated random walk (CRW) models, have become almost standard in invertebrate studies (Root and Kareiva 1984; McCulloch and Cain 1989), only recently have they been applied to large mammals (Bergman et al. 2000; Fortin et al. 2005). One study was able to explain individual variation of grey seals (Halichoerus grypus) with CRW-based models (Austin et al. 2004), demonstrating that spatial concepts developed in other taxonomic groups, such as invertebrates, can be successfully applied to carnivore studies.

Within spatial studies of carnivores, there has been a paucity of new ideas incorporating and testing theories developed in other fields. By applying spatial theories to carnivore research, we can further our understanding of their ecology, better predict population dynamics, and improve conservation practices for endangered and threatened carnivore species. The objective of this paper is to review studies of space use theories that, if applied, could enhance carnivore studies. We examine spatial theories tested in other taxonomic groups that could positively influence how carnivore biologists design studies. Specifically, we discuss some of the current quantitative methods available to spatial ecology, review four broad areas of spatial theory, and suggest methods to incorporate each into studies of spatial ecology of large terrestrial carnivores. Our ultimate goal is to encourage carnivore biologists to apply spatial theory to empirical studies that will advance the theoretical framework as well.

\section{Quantifying space use}

Animal movement studies have always faced the challenge of how to quantify space use (McCulloch and Cain 1989). Population-based (Logan et al. 1998; Macdonald and Rushton 2003) or individual-based (Huston et al. 1988; DeAngelis and Gross 1992; Haefner and Crist 1994; White and Gilligan 1998) spatial models are often implemented, but the assumptions of these models are difficult to meet. Diffusion models are often the basic starting point and assume animals move randomly (Skellam 1951), an assumption typically violated in carnivores because they have territories and repeatedly use the same areas, such as dens or rendezvous sites. Complexities have been added to diffusion models to better represent animal movement in the natural world (Shigesada 1980; Turchin 1989), but unrealistic assumptions still plague most diffusion models (Wiktorsson et al. 2004).

CRW models have received the most attention and fall between completely random models, such as diffusion models, and explicit individual-based models. CRW models assume that movement has a net directional bias but is random over discrete time intervals (Kareiva and Shigesada 1983; Bovet and Benhamou 1988; Turchin 1991). CRW models successfully describe and predict simple movement patterns (Root and Kareiva 1984; McCulloch and Cain 1989; Haefner and Crist 1994; Doak 2000; Byers 2001). A disadvantage of CRW models is that they may also be too simplistic to describe complex movement patterns. Repetitive movement patterns violate the assumptions of CRW models, and these models lose predictive power when scale complexity increases (Wiens et al. 1995), although some studies have attempted to control for this (Haefner and Crist 1994; Anderson et al. 1997; McIntyre and Wiens 1999; Byers 2001; Wiktorsson et al. 2004). Despite potential shortcomings, CRW models have been successfully applied to 
Table 1. Examples of carnivore studies that have tested and supported spatial theories developed in other taxonomic groups.

\begin{tabular}{lll}
\hline Theory tested & Species & Study \\
\hline Natal habitat preference induction & Coyote & Sacks et al. 2004, 2005 \\
Correlated random walk & Grey seals & Austin et al. 2004 \\
& Bottlenose dolphins & Bailey and Thompson 2006 \\
Relatedness affects space-use patterns & Brown bears & Stoen et al. 2005 \\
& Swift foxes & Kitchen et al. 2005 \\
& Black bears & Moyer et al. 2006 \\
Territory establishment & Badgers & Doncaster and Woodroffe 1993 \\
& Gray wolves & Smith et al. 1999 \\
Costs of territoriality & Black bears & Powell 2000 \\
& Leopards & Odden and Wegge 2005 \\
& African lions & Spong and Cree1 2004 \\
\hline
\end{tabular}

complex caribou (Rangifer tarandus) movement patterns over expansive spatial and temporal scales (Bergman et al. 2000). A modified CRW model was used to quantify the influences of gray wolf (Canis lupus) spatial patterns and habitat on elk (Cervus canadensis) spatial patterns (Fortin et al. 2005), suggesting that CRW models may provide insight into carnivore spatial ecology as well. In fact, one study applied a CRW model to spatial movement patterns of GPStagged grey seals (Austin et al. 2004). Although Austin et al. (2004) found that their CRW model could not describe movement patterns of more than half of the tagged seals, the model provided a useful method to evaluate causes of the lack of fit; thus, CRW models may be a starting point to quantify carnivore space use.

Fractal analysis models attempt to control for more complex scale issues. Fractal analysis determines the degree of tortuosity to predict the interaction of movement paths and landscape heterogeneity (Mandelbrot 1983; Dicke and Burrough 1988; Milne 1991). It has been used successfully to quantify movement and dispersal in beetles (Crist et al. 1992; Wiens et al. 1995), grasshoppers (With 1994), and birds (Westcott and Graham 2000; Doerr and Doerr 2004). Turchin (1996) pointed out that fractal analysis may still be scale-dependent and should be used only if independence is explicitly demonstrated, but Doerr and Doerr (2004) provided guidelines for effectively using fractal analysis without meeting assumptions of scale invariance.

Diffusion, fractal analysis, and CRW models rarely consider bounded space (Crist et al. 1992; Johnson et al. 1992; Wiens et al. 1993; Bengtsson et al. 2004) although most carnivores are likely bounded by fragmented habitats or physical and social barriers. Jeanson et al. (2003) developed a model that incorporates behaviors associated with bounded space (i.e., wall-following behavior) into a diffusive random walk. This may be an appropriate model for evaluating carnivore space use because it incorporates spatial structure into movement patterns, an important feature for models of species that encounter patchy landscapes and boundaries.

Although current models provide some predictive power for quantifying carnivore space use, it is unlikely that most carnivore systems can meet all of the assumptions within a given model. Scientists must instead determine which existing model provides the best biological explanation for their system while continuing to develop better models to evaluate spatial theories.

\section{Components of spatial theory}

\section{Conspecific attraction}

The conspecific attraction hypothesis assumes individuals make spatially explicit choices, such as which foraging patch to use or habitat to reside in, based on cues related to the presence of conspecifics (Stamps 1988; Muller et al. 1997). Stamps et al. (2005b) found support for conspecific attraction in female fruit flies (Drosophila melanogaster) and ghost crabs (Ocypode rotundata). Similarly, conspecific cues influence tubeworm (Galeolaria caespitosa) settlement patterns (Minchinton 1997) and are used by orb-web spiders (Nephilengys cruentata; Schuck-Paim and Alonso 2001) to determine web site locations.

There are two main challenges that carnivore biologists face when studying conspecific attraction. First, territoriality is common in large terrestrial carnivores, and territorial animals are rarely the focus of conspecific attraction studies. For example, conspecific attraction studies have focused on colonial rather than territorial birds (e.g., Podolsky 1990; Jeffries and Brunton 2001). Second, most carnivore studies are limited by sample size and compensate for this by focusing on high-density areas.

Both challenges can be overcome. Ward and Schlossberg (2004) conducted an experimental study demonstrating conspecific attraction in an endangered territorial bird, and there is evidence that it occurs in other territorial species as well (Alatalo et al. 1982; Stamps 1988; Muller et al. 1997; Tarof and Ratcliffe 2000; Sergio and Penteriani 2005). Because social aggregations of territorial species are commonly observed (Desroches 2003), Ward and Schlossberg's (2004) study design could be used as a guideline for carnivore biologists. Their study focused on areas that contained good habitat but were not being used by the focal bird species. Within selected high-quality areas, they used a series of playbacks, dummy birds, and a combination of the two to determine whether conspecifics influenced the likelihood of settlement (Ward and Schlossberg 2004). Playbacks have been used successfully for studies of intraguild predator avoidance tactics of cheetahs (Acinonyx jubatus; Durant 2000); territorial responses from conspecific carnivores have been evaluated with playbacks (Spong and Creel 2004); and dummy African lions have been used to evaluate conspecific behavioral responses (West and Packer 2002). These examples suggest that techniques similar to those used in Ward 
and Schlossberg's (2004) study can be applied to test conspecific attraction in carnivore species. Carnivore studies could use these tools in areas where carnivores are less dense or currently absent, allowing comparisons with areas of high density. A research program that works in concert with a carnivore reintroduction or translocation program would provide a good model system and both would gain long-term benefits from testing the conspecific attraction hypothesis (Stamps and Swaisgood 2007).

\section{Territory establishment}

Factors that influence how an individual determines where to establish a home range or territory include natal experience (Glück 1984; Davis and Stamps 2004), intraspecific interactions (Stamps and Krishnan 1999), availability of space (Larsen and Boutin 1995), conspecific attraction (Stamps 1988), and variation in individual behavior (Katano et al. 2004). Katano et al. (2004) found that individual variation and costs of defense affected territory establishment in a river bottom fish, the ayu (Plecoglossus altivelis). Individual behavioral differences are commonly observed in carnivores, but how these differences relate to territory establishment has seldom been studied. Variation in boldness behaviors of captive individual swift foxes (Vulpes velox) was related to post-release survival (Bremner-Harrison et al. 2004) and may represent an important behavioral trait influencing territory establishment in carnivores.

Home range establishment is also influenced by exploratory movements, for example in insects (Wang and Greenfield 1994), amphibians (Lamoureux et al. 2002), and birds (Doerr and Doerr 2005). Forays are also observed in mammals, but most studies have concluded that exploratory movements work in conjunction with other factors to influence territory establishment. For example, Haughland and Larsen (2004) found that exploratory movement and available space equally influenced settlement of North American red squirrels (Tamiasciurus hudsonicus).

Once an area is obtained, an animal must define and maintain its boundaries. Spatial avoidance of areas where negative interactions previously occurred may create territory boundaries (Stamps and Krishnan 2001), and models predict territory boundary patterns based upon interactions with neighbors (White et al. 1996; Adams 1998). Although interactions between neighbors can create observed territory shapes and boundaries (Morrell and Kokko 2005), landscape features may also influence territory boundaries (Eason et al. 1999; Partecke et al. 2002; LaManna and Eason 2003). Using landmarks as territory boundaries reduces defensive costs of territoriality (Eason et al. 1999), which may explain its practice by many territorial species.

Experimentally determining the influence of landmarks on the establishment of territory boundaries in large carnivores may be challenging because the landmarks used by the animals are often features that cannot be easily manipulated (e.g., rivers as territory borders between coyote packs; Gese et al. 1996). Man-made features are easier to manipulate than natural features, and carnivores with smaller territories provide model systems to conduct such experiments. By removing or adding features (e.g., fence lines) in a relatively homogeneous landscape, researchers could experimentally determine the effects of landscape features on territory boundaries. Landmarks that may have been historically used by carnivores to define territory boundaries are also modified through changes in land use, such as new roads and houses. Although development projects may not be ideal for conservation, they provide opportunities to conduct natural experiments that explore the influence of landmarks on carnivore territory boundaries.

Carnivore biologists can also take advantage of opportunities that arise when carnivores naturally repopulate areas where they were locally extirpated or within the context of carnivore reintroduction programs. For example, coyotes (Canis latrans) are often locally extirpated through removal programs but quickly repopulate the area once removal programs end (Blejwas et al. 2002). Doncaster and Woodroffe (1993) researched the territory establishment processes of badgers (Meles meles) in an area where badgers had been eradicated. Gray wolves are recolonizing the Alps (Scandura et al. 2001) and brown bears (Ursus arctos) are expanding their range in Scandinavia (Swenson et al. 1998), providing more opportunities to study establishment processes.

Territory establishment can also be evaluated during reintroduction and translocation programs. Experimentally released Eurasian beavers (Castor fiber) were studied along with an established population to test the effect of territory settlement timing on space use patterns (Nolet and Rosell 1994). Nolet and Rosell (1994) tested hypotheses related to territorial resource needs and the influence of established neighbors by sequentially releasing beavers at the experimental site. This study exemplifies a method that is effective with mammals and could enable carnivore biologists to test territory establishment hypotheses. Reintroduction of the gray wolf in Yellowstone National Park provided a great opportunity to observe territory establishment processes in a highly social canid (Smith et al. 1999). Past opportunities involving carnivore translocations have yielded some information on individual spatial responses (Ruth et al. 1998) but have been underutilized for evaluating territory establishment processes. By designing studies that could test spatial theory before translocations and reintroductions occur, carnivore biologists could objectively evaluate the reasons why a reintroduction or translocation did or did not succeed and how to improve future programs.

\section{Within-territory space use}

An animal should defend a territory if the benefits accrued via familiarity with a site outweigh the costs incurred by remaining at that site (Stamps 1995; Powell 2000). How that territorial space is used is a function of several factors. These factors include habitat, prey distribution, and space use patterns of neighbors and are not mutually exclusive. Most studies of within-territory spatial patterns have focused on determining core areas (Samuel et al. 1985) or utilization distributions (Neu et al. 1974; Van Winkle 1975; Kernohan et al. 2001). These methods provide a static picture that does not evaluate decision-making rules that create emergent spatial patterns (Austin et al. 2004). Several reviews and evaluations of the methodological approach to estimators have already been published (Swihart and Slade 1985; Worton 1987; Seaman and Powell 1996; Hansteen et al. 1997; Hemson et al. 2005) and, therefore, will not be 
discussed here. Instead, we focus on mechanisms that determine within-territory space use.

Within-territory space use may be adjusted in response to conspecifics. Eason and Hannon (2003) documented space use patterns of willow ptarmigan (Lagopus lagopus) and found that once a male paired with a female, he rarely used the non-core area of his territory frequented by nonterritorial males. Instead, paired males remained near the female in the core area. Similarly, Switzer and Eason (2003) determined that territorial male amberwing dragonflies (Perithemis tenera) use a simple decision-making rule to govern space use: move closer to females and move away from intruding males. Wolf et al. (1997), however, found no territorial effects of neighbors for white-faced dragonflies (Leucorrhinia intacta). These studies illustrate methods for determining how encountering different conspecifics affects space use within territories.

Territorial space use may be a product of simple decisionmaking rules when territories have low structural complexity, but species with more structurally complex territories likely make more complex space use decisions. Space use complexities likely include constraints related to environmental conditions, energy (McNicol and Noakes 1981), prey distribution, or predation risk (Wolf et al. 1997). Predation risk altered space use patterns of a predatory wolf spider (Pardosa milvina; Wilder and Rypstra 2004). Spatial interactions can affect the strength of interference competition (Reznikova and Dorosheva 2004) and mediate the coexistence of predator and prey species in their natural environment (but see Amarasekare 2000). Natural and artificial patterns of prey distribution can also affect predator space use (Pitt and Ritchie 2002). For example, translocations of bighorn sheep (Ovis canadensis) may profoundly affect spatial patterns of their main predator, mountain lions (Puma concolor), yet no study has evaluated the interaction beyond determining mountain lion predation rates (Rominger et al. 2004). Thus, it is important to determine how carnivores are responding to spatial patterns of predators, competitors, and prey species in addition to conspecifics.

Most carnivore studies recognize complexities and evaluate more specific factors of territorial space use. Studies have obtained territory and core area size estimates, determined habitat use, compared group size and prey availability with territory size, and more. While this detail has increased our understanding of carnivores, the basic assumptions of the costs and benefits of territoriality are rarely tested. These assumptions have been rejected in other areas of mammalogy. For example, the assumption that territory size is determined by what is economically defendable was rejected in an experimental study of Eurasian beavers (Campbell et al. 2005). Experimental manipulations of resource availability within carnivore territories could be used to identify the cost and benefit thresholds of territoriality. Carnivore biologists should first test some of the basic assumptions and then focus on the mechanisms that drive observed territorial spatial patterns.

\section{Heritability of space use}

Individual and population variation may result from maternal effects and previous experience, but proximate ex- planations of variation may include the role of genetically inherited traits. Exploratory movements, dispersal events, and settlement patterns illustrate space use behaviors influenced by genetically inherited traits.

Dispersal is particularly relevant for research of large carnivores because factors such as habitat fragmentation and human encroachment may alter natural dispersal patterns and ultimately lead to population declines. Even though dispersal is important, it is often difficult to study. Difficulties arise because studies are constrained by size of the study area, low sample sizes of genetically known individuals, or inability to distinguish the impacts of long-distance dispersal from those of short-distance dispersal (Trakhtenbrot et al. 2005). Even studies conducted on small invertebrates in a laboratory face restrictions with regard to study size (Sokolowski et al. 1986; Hoffmann 1987; Drickamer and Gillie 1998), and further complications arise when studying carnivores that use extremely large areas (Ruckelshaus et al. 1997). For example, the most intensive study of dispersal and genetic relatedness of African wild dogs (Lycaon pictus) used a population that was partially bounded by an electrified fence (Girman et al. 1997), likely constraining inference. Sample and study site size restrictions typically associated with carnivore research mean that dispersal information may be difficult to obtain, often leaving carnivore biologists with little more than anecdotal evidence from chance events. To overcome limitations, new methods to model individual variation in dispersal movement patterns are emerging (Doerr and Doerr 2005; Vuilleumier and Metzger 2006), and advances in technology, such as GPS collars, are aiding empirical studies (Bennetts et al. 2001).

New methods in genetics also have aided studies of dispersal and other movement patterns, but high costs and unreliability of some noninvasive sampling techniques prohibit most studies from using genetic techniques. In fact, only a few published studies have been able to control for both study area and genetic variation to determine that genetic differences influence spacing behavioral traits (Howery et al. 1998; Stamps et al. 2005a). By using multiple lineages of genetically identical fruit flies, Stamps et al. (2005a) showed that site fidelity and temporal patterns of space partitioning are influenced by genetically inherited traits.

Despite the difficulties, possibilities exist for evaluating the role of inheritance of space use in large terrestrial carnivores. While observational studies may provide a general framework, most carnivores are long-lived, making this approach impractical unless it is combined with alternative approaches such as genetic research. Stoen et al. (2005) successfully applied a genetic approach to a long-term study of the spatial ecology of brown bears and Kitchen et al. (2005) used genetic data on relatedness to evaluate observed spatial patterns of swift foxes. Experimental approaches may be more cost-effective and more appropriate for studies that do not have long-term data sets or funding for genetic analyses. Cross-fostering is an experimental approach that can help tease apart the social, environmental, and genetic influences on distribution patterns (Howery et al. 1998). Coyote pups have already been successfully cross-fostered (Kitchen and Knowlton 2006), thus providing an opportunity to test the role of inheritance in carnivore space use patterns. 


\section{Implications, challenges, and future direction}

Space use theories are now incorporated into a vast range of studies, including studies on epidemiology (Ostfeld et al. 2005; Woodroffe et al. 2005) and reserve designs (Stockhausen et al. 2000; Williams et al. 2005). As field and quantitative techniques continuously advance spatial ecology, our understanding of mechanisms of space use and population dynamics will expand. We must continue to develop better methods of analysis and be vigilant for ideas that are developed in other areas that could be applied to studies of carnivore ecology.

Applying theory developed in other taxonomic groups to carnivore ecology has two major limitations: availability of techniques and issues of scale. While some techniques that evaluate space use theories are not applicable to studies of large terrestrial carnivores, others may be highly suitable, and still others may just take some creativity in design to be useful. Cross-scale methods are developing (Nakaoka and Noda 2004; Gautestad and Mysterud 2005) and studies at fine scales are becoming more applicable to large-scale movement patterns (Bengtsson et al. 2004; Underwood et al. 2005), thus creating more opportunities for carnivore biologists to work within the theoretical framework of spatial ecology developed in other fields.

The purpose of this review was to reveal some of the opportunities that exist to advance the field of carnivore spatial ecology by drawing upon studies conducted with other taxonomic groups and pointing out examples where spatial theory has been successfully studied in carnivores (Table 1), because researchers studying other taxonomic groups, such as insects, have surpassed carnivore biologists' understanding of theoretical space use and how these theories can be tested empirically. Spatial theories should not be tested in carnivore systems just for the sake of testing theories, but to help with management and conservation of carnivores. Knowledge gained from carnivore studies that use a theoretical framework could dramatically influence reintroduction programs, management plans to reduce carnivore-human conflict, and endangered species recovery plans. In the process of investigation, new theories may evolve that further enhance our understanding of carnivore ecology and, ultimately, improve the field of spatial ecology itself.

\section{Acknowledgements}

Discussions with K. Sullivan and J. Altmann helped in the development of this review. T. Atwood, H. Weaver, R. Wulff, E. Gese, and two anonymous reviewers provided excellent editorial suggestions.

\section{References}

Adams, E.S. 1998. Territory size and shape in fire ants: a mode1 based on neighborhood interactions. Ecology, 79: 1125-1134. doi: $10.2307 / 176731$

Alatalo, R.V., Lundberg, A., and Bjorklund, M. 1982. Can the song of male birds attract other males? An experiment with the pied flycatcher Ficedula hypoleuca. Bird Behav. 4: 42-45.

Amarasekare, P. 2000. Spatial dynamics in a host-multiparasitoid community. J. Anim. Ecol. 69: 201-213. doi:10.1046/j.13652656.2000.00378.x.
Anderson, A.R.A., Young, I.M., Sleeman, B.D., Griffiths, B.S., and Robertson, W.M. 1997. Nematode movement along a chemical gradient in a structurally heterogeneous environment: 1. Experiment. Fundam. Appl. Nematol. 20: 157-163.

Austin, D., Bowen, W.D., and McMillan, J.I. 2004. Intraspecific variation in movement patterns: modeling individual behaviour in a large predator. Oikos, 105: 15-30. doi:10.1111/j.00301299.1999.12730.x.

Bailey, H., and Thompson, P. 2006. Quantitative analysis of bottlenose dolphin movement patterns and their relationship with foraging. J. Anim. Ecol. 75: 456-465. doi:10.1111/j.1365-2656. 2006.01066.x. PMID: 16637998.

Bengtsson, G., Nilsson, E., Ryden, T., and Wiktorsson, M. 2004. Irregular walks and loops combine in small-scale movement of a soil insect: implication for dispersal biology. J. Theor. Biol. 231: 299-306. doi:10.1016/j.jtbi.2004.06.025. PMID:15380394.

Bennetts, R.E., Nichols, J.D., Lebreton, J.D., Pradel, R., Hines, J.E., and Kitchens, W.M. 2001. Methods for estimating dispersal probabilities and related parameters using marked animals. In Dispersal. Edited by J. Clobert, E. Danchin, A.A. Dhondt, and J.D. Nichols. Oxford University Press, Oxford. pp. 3-17.

Bergman, C.M., Schaefer, J.A., and Luttich, S.N. 2000. Caribou movement as a correlated random walk. Oecologia, 123: 364374. doi: $10.1007 / \mathrm{s} 004420051023$.

Bertram, B.C.R. 1979. Home range of a hingeback tortoise in the Serengeti. Afr. J. Ecol. 17: 241-244.

Blejwas, K.M., Sacks, B.N., Jaeger, M.M., and McCullough, D.R. 2002. The effectiveness of selective removal of breeding coyotes in reducing sheep predation. J. Wildl. Manag. 66: 451-462.

Bovet, P., and Benhamou, S. 1988. Spatial analysis of animal movements using a correlated random walk model. J. Theor. Biol. 131: 419-433. doi:10.1016/S0022-5193(88)80038-9.

Bremner-Harrison, S., Prodohl, P.A., and Elwood, R.W. 2004. Behavioural trait assessment as a release criterion: boldness predicts early death in a reintroduction programme of captive-bred swift fox (Vulpes velox). Anim. Conserv. 7: 313-320. doi:10. $1017 / \mathrm{S} 1367943004001490$.

Buck, S., Mullis, C., and Mossman, A. 1979. A radiotelemetry study of fishers in northwestern California. Trans. Cal.-Nev. Wildl. 1979: 166-172.

Byers, J.A. 2001. Correlated random walk equations of animal dispersal resolved by simulation. Ecology, 82: 1680-1690. doi:10. 2307/2679810.

Campbell, R.D., Rosell, F., Nolet, B., and Dijkstra, V.A.A. 2005. Territory and group size in Eurasian beavers (Castor fiber): echoes of settlement and reproduction? Behav. Ecol. Sociobiol. 58: 597-607. doi:10.1007/s00265-005-0942-6.

Claussen, D.L., Finkler, M.S., and Smith, M.M. 1997. Thread trailing of turtles: methods for evaluating spatial movements and pathway structure. Can. J. Zool. 75: 2120-2128.

Cochran, W.W., Montgomery, G.G., and Graber, R.R. 1967. Migratory flights of hylocichla thrushes in spring: a radiotelemetry study. Living Bird, 6: 213-225.

Crist, T.O., Guertin, D.S., Wiens, J.A., and Milne, B.T. 1992. Animal movement in heterogeneous landscapes: an experiment with Eleodes beetles in shortgrass prairie. Funct. Ecol. 6: 536-544. doi: $10.2307 / 2390050$.

Davis, J.M., and Stamps, J.A. 2004. The effect of natal experience on habitat preferences. Trends Ecol. Evol. 19: 411-416. doi:10. 1016/j.tree.2004.04.006. PMID:16701298.

DeAngelis, D.L., and Gross, L.J. (Editors). 1992. Individual-based models and approaches in ecology: population, communities, and ecosystems. Chapman and Hall, New York.

Desroches, A. 2003. Bridging the gap: linking individual bird 
movement and territorial establishment rules with their patterns of distribution in fragmented forests. In Animal behavior and wildlife conservation. Edited by M. Festa-Bianchet and M. Appolonio. Island Press, Washington, D.C. pp. 63-76.

Dicke, M., and Burrough, P.A. 1988. Using fractal dimensions for characterizing tortuosity of animal traits. Physiol. Entomol. 13: 393-398.

Doak, P. 2000. Population consequences of restricted dispersal for an insect herbivore in a subdivided habitat. Ecology, 81: 18281841. doi: $10.2307 / 177274$

Doerr, E.D., and Doerr, V.A. 2005. Dispersal range analysis: quantifying individual variation in dispersal behaviour. Oecologia, 142: 1-10. doi:10.1007/s00442-004-1707-z. PMID:15378345.

Doerr, V.A., and Doerr, E.D. 2004. Fractal analysis can explain individual variation in dispersal search patterns. Ecology, 85: 1428-1438.

Doncaster, C.P., and Woodroffe, R. 1993. Den site can determine shape and size of badger territories - implications for group-living. Oikos, 66: 88-93.

Drickamer, L.C., and Gillie, L.L. 1998. Integrating proximate and ultimate causation in the study of vertebrate behavior - methods and considerations. Am. Zool. 38: 43-58.

Durant, S. 2000. Living with the enemy: avoidance of hyenas and lions by cheetahs in the Serengeti. Behav. Ecol. 11: 624-632. doi:10.1093/beheco/11.6.624.

Eason, P.K., and Hannon, S.J. 2003. Effect of pairing status on use of space by territorial willow ptarmigan (Lagopus lagopus): bachelor males choose life on the edge. Auk, 120: 497-504. doi:10.1642/0004-8038(2003)120[0497:EOPSOU]2.0.CO;2.

Eason, P.K., and Switzer, P.V. 2004. The costs of neighbors for a territorial dragonfly, Perithemis tenera. Ethology, 110: 37-47. doi:10.1046/j.1439-0310.2003.00942.x.

Eason, P.K., Cobbs, G.A., and Trinca, K.G. 1999. The use of landmarks to define territorial boundaries. Anim. Behav. 58: 85-91. doi:10.1006/anbe.1999.1133. PMID:10413544.

Fortin, D., Beyer, H.L., Boyce, M.S., Smith, D.W., Duchesne, T., and Mao, J.S. 2005. Wolves influence elk movements: behavior shapes a trophic cascade in Yellowstone National Park. Ecology, 86: $1320-1330$.

Gaskin, D.E., Smith, G.J.D., and Watson, A.P. 1975. Preliminary movements of harbor porpoises (Phocoena phocoena) in the Bay of Fundy using radiotelemetry. Can. J. Zool. 53: 1466-1471.

Gautestad, A.O., and Mysterud, I. 2005. Intrinsic scaling complexity in animal dispersion and abundance. Am. Nat. 165: 44-55. doi:10.1086/426673. PMID:15729639.

Gese, E.M., Ruff, R.L., and Crabtree, R. 1996. Foraging ecology of coyotes (Canis latrans): influence of extrinsic factors and a dominance hierarchy. Can. J. Zool. 74: 769-783.

Getty, T. 1987. Dear enemies and the prisoner's dilemma: why should territorial neighbors form defensive coalitions? Am. Zool. 27: 327-336.

Girman, D.J., Mills, M.G.L., Geffen, E., and Wayne, R.K. 1997. A molecular genetic analysis of social structure, dispersal, and interpack relationships of the African wild dog (Lycaon pictus). Behav. Ecol. Sociobiol. 40: 187-198. doi:10.1007/s002650050332.

Glück, E. 1984. Habitat selection in birds and the role of early experience. Z. Tierpsychol. 66: 45-54.

Haefner, J.W., and Crist, T.O. 1994. Spatial model of movement and foraging in harvester ants (Pogonomyrmex) (I): the roles of memory and communication. J. Theor. Biol. 166: 299-313. doi:10.1006/jtbi.1994.1027.

Hansteen, T.L., Andreassen, H.P., and Ims, R.A. 1997. Effects of spatiotemporal scale on autocorrelation and home range estimators. J. Wildl. Manag. 61: 280-290.
Haughland, D.L., and Larsen, K.W. 2004. Exploration correlates with settlement: red squirrel dispersal in contrasting habitats. J. Anim. Ecol. 73: 1024-1034. doi:10.1111/j.0021-8790.2004.00884.x.

Hemson, G., Johnson, P., South, A., Kenward, R., Ripley, R., and Macdonald, D. 2005. Are kernels the mustard? Data from global positioning system (GPS) collars suggests problems for kernel home-range analyses with least-squares cross-validation. J. Anim. Ecol. 74: 455-463.

Hoffmann, A.A. 1987. A laboratory study of male territoriality in the sibling species Drosophila melanogaster and D. simulans. Anim. Behav. 35: 807-818. doi:10.1016/S0003-3472(87)80117-3.

Howery, L.D., Provenza, F.D., Banner, R.E., and Scott, C.B. 1998. Social and environmental factors influence cattle distribution on rangeland. Appl. Anim. Behav. Sci. 55: 231-244. doi:10.1016/ S0168-1591(97)00054-3.

Huston, M., DeAngelis, D., and Post, W. 1988. New computer models unifying ecological theory. Bioscience, 38: 682-691. doi: $10.2307 / 1310870$.

Jeanson, R., Blanco, S., Fournier, R., Deneubourg, J., Fourcassié, V., and Theraulaz, G. 2003. A model of animal movements in bounded space. J. Theor. Biol. 225: 443-451. doi:10.1016/ S0022-5193(03)00277-7. PMID:14615202.

Jeffries, D.S., and Brunton, D.H. 2001. Attracting endangered species to 'safe' habitats: responses of Fairy Terns to decoys. Anim. Conserv. 4: 301-305.

Johnson, A.R., Wiens, J.A., Milne, B.T., and Crist, T.O. 1992. Animal movements and population dynamics in heterogeneous landscapes. Landsc. Ecol. 7: 63-75.

Kareiva, P. 1994. Space: the final frontier for ecological theory. Ecology, 75: 1. doi:10.2307/1939376.

Kareiva, P., and Shigesada, N. 1983. Analyzing insect movement as a correlated random walk. Oecologia, 56: 234-238. doi:10. 1007/BF00379695.

Katano, O., Uchida, K., and Aonuma, Y. 2004. Experimental analysis of the territorial establishment of ayu, Plecoglossus altivelis. Ecol. Res. 19: 433-444. doi:10.1111/j.1440-1703.2004.00654.x.

Kernohan, B.J., Gitzen, R.A., and Millspaugh, J.J. 2001. Analysis of animal space use and movements. In Radio tracking and animal populations. Edited by J.J. Millspaugh and J.M. Marzluff. Academic Press, San Diego. pp. 125-166.

Kitchen, A.M., and Knowlton, F.F. 2006. Evaluation of crossfostering among canids: a conservation and research tool. Biol. Conserv. 129: 221-225. doi:10.1016/j.biocon.2005.10.036.

Kitchen, A.M., Gese, E.M., Waits, L.P., Karki, S.M., and Schauster, E.R. 2005. Genetic and spatial structure within a swift fox population. J. Anim. Ecol. 74: 1173-1181. doi:10.1111/j.13652656.2005.01017.x.

Korniss, G., and Caraco, T. 2005. Spatial dynamics of invasion. J. Theor. Biol. 233: 137-150. doi:10.1016/j.jtbi.2004.09.018.

LaManna, J.R., and Eason, P.K. 2003. Effects of landmarks on territorial establishment. Anim. Behav. 65: 471-478. doi:10.1006/ anbe.2003.2095.

Lamoureux, V.S., Maerz, J.C., and Madison, D.M. 2002. Premigratory autumn foraging forays in the green frog, Rana clamitans. J. Herpetol. 36: 245-254.

Larsen, K.W., and Boutin, S. 1995. Exploring territory quality in the North American red squirrel through removal experiments. Can. J. Zool. 73: 1115-1122.

Lindström, E. 1986. Territory inheritance and the evolution of group-living in carnivores. Anim. Behav. 34: 1825-1835. doi:10.1016/S0003-3472(86)80268-8.

Logan, J.A., White, P., Bentz, B.J., and Powell, J.A. 1998. Model analysis of spatial patterns in mountain pine beetle outbreaks. Theor. Popul. Biol. 53: 236-255. PMID:9682026. 
Macdonald, D.W. 1983. The ecology of carnivore social behaviour. Nature (London), 301: 379-384. doi:10.1038/301379a0.

Macdonald, D.W., and Rushton, S. 2003. Modelling space use and dispersal of mammals in real landscapes: a tool for conservation. J. Biogeogr. 30: 607-620.

Mandelbrot, B.B. 1983. The fractal geometry of nature. W.H. Freeman, New York.

Maynard Smith, J.P., and Price, G.R. 1973. The logic of animal conflict. Nature (London), 246: 15-18. doi:10.1038/246015a0.

McCulloch, C.E., and Cain, M.L. 1989. Analyzing discrete movement data as a correlated random walk. Ecology, 70: 383-388. doi: $10.2307 / 1937543$.

McIntyre, N.E., and Wiens, J.A. 1999. Interactions between landscape structure and animal behavior: the roles of heterogeneously distributed resources and food deprivation on movement patterns. Landsc. Ecol. 14: 437-447. doi:10.1023/ A: 1008074407036 .

McNicol, R.E., and Noakes, D.L.G. 1981. Territories and territorial defense in juvenile brook char, Salvelinus fontinalis (Pisces: Salmonidae). Can. J. Zool. 59: 22-28.

Milne, B.T. 1991. Lessons from applying fractal models to landscape patterns. In Quantitative methods in landscape ecology. Edited by M.G. Turner and R.H. Gardner. Springer-Verlag, New York. pp. 199-235.

Minchinton, T.E. 1997. Life on the edge: conspecific attraction and recruitment of populations to disturbed habitats. Oecologia, 111: 45-52. doi: $10.1007 / \mathrm{s} 004420050206$.

Morrell, L.J., and Kokko, H. 2005. Bridging the gap between mechanistic and adaptive explanations of territory formation. Behav. Ecol. Sociobiol. 57: 381-390. doi:10.1007/s00265-0040859-5.

Moyer, M.A., Walter McCown, J., Eason, T.H., and Oli, M.K. 2006. Does genetic relatedness influence space use pattern? A test on Florida black bears. J. Mammal. 87: 255-261.

Muller, K.L., Stamps, J.A., Krishnan, V.V., and Willits, N.H. 1997. The effects of conspecific attraction and habitat quality on habitat selection in territorial birds (Troglodytes aedon). Am. Nat. 150: $650-661$. doi: $10.1086 / 286087$.

Nakaoka, M., and Noda, T. 2004. Special feature: multiple spatial scale approaches in population and community ecology. Popul. Ecol. 46: 103-104.

Neu, C.W., Byers, C.R., and Peek, J.M. 1974. A technique for analysis of utilization-distribution data. J. Wildl. Manag. 38: 541-545.

Nolet, B.A., and Rosell, F. 1994. Territoriality and time budgets in beavers during sequential settlement. Can. J. Zool. 72: 1227-1237.

Odden, M., and Wegge, P. 2005. Spacing and activity patterns of leopards Panthera pardus in the Royal Bardia National Park, Nepal. Wildl. Biol. 11: 145-152.

Ostfeld, R.S., Glass, G.E., and Keesing, F. 2005. Spatial epidemiology: an emerging (or re-emerging) discipline. Trends Ecol. Evol. 20: 328-336. doi:10.1016/j.tree.2005.03.009. PMID:16701389.

Partecke, J., von Haeseler, A., and Wikelski, M. 2002. Territory establishment in lekking marine iguanas, Amblyrhynchus cristatus: support for the hotshot mechanism. Behav. Ecol. Sociobiol. 51: 579-587. doi:10.1007/s00265-002-0469-z.

Pitt, W.C., and Ritchie, M.E. 2002. Influence of prey distribution on the functional response of lizards. Oikos, 96: 157-163. doi:10.1034/j.1600-0706.2002.960117.x.

Podolsky, R.H. 1990. Effectiveness of social stimuli in attracting Laysan Albatross to new potential nesting sites. Auk, 107: 119-125.

Powell, R.A. 2000. Animal home ranges and territories and home range estimators. In Research techniques in animal ecology: controversies and consequences. Edited by L. Boitani and T.K. Fuller. Columbia University Press, New York. pp. 65-110.
Reznikova, Z., and Dorosheva, H. 2004. Impacts of red wood ants Formica polyctena on the spatial distribution and behavioural patterns of ground beetles (Carabidae). Pedobiologia, 48: 15-21.

Rominger, E.M., Whitlaw, H.A., Weybright, D.L., Dunn, W.C., and Ballard, W.B. 2004. The influence of mountain lion predation on bighorn sheep translocations. J. Wildl. Manag. 68: 993-999.

Root, R.B., and Kareiva, P.M. 1984. The search for resources by cabbage butterflies (Pieris rapae): ecological consequences and adaptive significance of Markovian movements in a patchy environment. Ecology, 65: 147-165. doi:10.2307/1939467.

Ruckelshaus, M., Hartway, C., and Kareiva, P.M. 1997. Assessing the data requirements of spatially explicit dispersal models. Conserv. Biol. 11: 1298-1306. doi:10.1046/j.1523-1739.1997.96151.x.

Ruth, T.K., Logan, K.A., Sweanor, L.L., Hornocker, M.G., and Temple, L.J. 1998. Evaluating cougar translocation in New Mexico. J. Wildl. Manag. 62: 1264-1275.

Sacks, B.N., Brown, S.K., and Ernest, H.B. 2004. Population structure of California coyotes corresponds to habitat-specific breaks and illuminates species history. Mol. Ecol. 13: 1265-1275. doi:10.1111/j.1365-294X.2004.02110.x. PMID:15078462.

Sacks, B.N., Mitchell, B.R., Williams, C.L., and Ernest, H.B. 2005. Coyote movements and social structure along a cryptic population genetic subdivision. Mol. Ecol. 14: 1241-1249. doi:10. $1111 /$ j.1365-294X.2005.02473.x. PMID:15773950.

Sale, P.F. 1975. Patterns of use of space in a guild of territorial reef fishes. Mar. Biol. (Ber1.), 29: 88-97.

Samuel, M.D., Pierce, D.J., and Garton, E.O. 1985. Identifying areas of concentrated use within the home range. J. Anim. Ecol. 57: $1067-1068$.

Scandura, M., Appolonio, M., and Mattioli, L. 2001. Recent recovery of the Italian wolf population: a genetic investigation using microsatellites. Mamm. Biol. 66: 321-331.

Schuck-Paim, C., and Alonso, W.J. 2001. Deciding where to settle: conspecific attraction and web site selection in the orb-web spider. Anim. Behav. 62: 1007-1012.

Seaman, D.E., and Powell, R.A. 1996. An evaluation of the accuracy of kernel density estimators for home range analysis. Ecology, 77: 2075-2085. doi:10.2307/2265701.

Sergio, F., and Penteriani, V. 2005. Public information and territory establishment in a loosely colonial raptor. Ecology, 86: 340-346.

Shigesada, N. 1980. Spatial distribution of dispersing animals. J. Math. Biol. 9: 85-96. doi:10.1007/BF00276037. PMID:7365329.

Skellam, J.G. 1951. Random dispersal in theoretical populations. Biometrika, 38: 196-218. doi:10.2307/2332328. PMID:14848123.

Smith, D.W., Brewster, W.G., and Bangs, E.E. 1999. Wolves in the greater Yellowstone ecosystem: restoration of a top carnivore in a complex management environment. In Carnivores in ecosystems: the Yellowstone experience. Edited by T.W. Clark, A.P. Curlee, S.C. Minta, and P.M. Kareiva. Yale University Press, New Haven, Conn. pp. 103-125.

Sokolowski, M.B., Bauer, S.J., Wai-Ping, V., Rodriguez, L., Wong, R.L., and Kent, C. 1986. Ecological genetics and behaviour of Drosophila melanogaster larvae in nature. Anim. Behav. 34: 403-408. doi:10.1016/S0003-3472(86)80109-9.

Speake, D.W., and McGlincy, J.A. 1981. Response of indigo snakes to gassing of their dens. Proc. Annu. Conf. Southeast. Assoc. Fish Wildl. Agencies, 35: 135-138.

Spong, G., and Creel, S. 2004. Effects of kinship on territorial conflicts among groups of lions, Panthera leo. Behav. Ecol. Sociobiol. 55: 325-331. doi:10.1007/s00265-003-0723-z.

Stahl, P., Vandel, J.M., Ruette, S., Coat, L., Coat, Y., and Balestra, L. 2002. Factors affecting lynx predation on sheep in the French Jura. J. Appl. Ecol. 39: 204-216. doi:10.1046/j.1365-2664.2002. 00709.x. 
Stamps, J.A. 1988. Conspecific attraction and aggregation in territorial species. Am. Nat. 131: 329-347. doi:10.1086/284793.

Stamps, J.A. 1995. Motor learning and the value of familiar space. Am. Nat. 146: 41-58. doi:10.1086/285786.

Stamps, J.A., and Krishnan, V.V. 1997. The function of fights in territory establishment. Am. Nat. 150: 393-405. doi:10.1086/ 286071.

Stamps, J.A., and Krishnan, V.V. 1999. A learning-based model of territory establishment. Q. Rev. Biol. 74: 291-318. doi:10.1086/ 393163.

Stamps, J.A., and Krishnan, V.V. 2001. How territorial animals compete for divisible space: a learning-based model with unequal competitors. Am. Nat. 157: 154-169. doi:10.1086/318634.

Stamps, J.A., and Swaisgood, R.R. 2007. Someplace like home: experience, habitat selection and conservation biology. In Special issue: Animal behaviour, conservation and enrichment. Applied animal behaviour science. Edited by R. Swaisgood. In press.

Stamps, J.A., Buechner, M., Alexander, K., Davis, J., and Zunigas, N. 2005a. Genotypic differences in space use and movement patterns in Drosophila melanogaster. Anim. Behav. 70: 609618. doi:10.1016/j.anbehav.2004.11.018.

Stamps, J.A., McElreath, R., and Eason, P. 2005b. Alternative models of conspecific attraction in flies and crabs. Behav. Ecol. 16: 974-980. doi:10.1093/beheco/ari083.

Stockhausen, W.T., Lipcius, R.N., and Hickey, B.M. 2000. Joint effects of larval dispersal, population regulation, marine reserve design, and exploitation on production and recruitment in the Caribbean spiny lobster. Bull. Mar. Sci. 66: 957-990.

Stoen, O.G., Bellemain, E., Saebo, S., and Swenson, J.E. 2005. Kin-related spatial structure in brown bears Ursus arctos. Behav. Ecol. Sociobiol. 59: 191-197. doi:10.1007/s00265-005-0024-9.

Swenson, J.E., Sandegren, F., and Söderberg, A. 1998. Geographic expansion of an increasing brown bear population: evidence for presaturation dispersal. J. Anim. Ecol. 67: 819-826. doi:10. 1046/j.1365-2656.1998.00248.x.

Swihart, R.K., and Slade, N.A. 1985. Testing for independence of observations in animal movements. Ecology, 66: 1176-1184. doi: $10.2307 / 1939170$

Switzer, P.V., and Eason, P.K. 2003. Space use in territorial amberwing dragonflies: are residents female maximizers or neighbor minimizers? Behav. Ecol. Sociobiol. 54: 321-328. doi:10. 1007/s00265-003-0650-z.

Tarof, S.A., and Ratcliffe, L.M. 2000. Pair formation and copulation behavior in least flycatcher clusters. Condor, 102: 832-837. doi:10.1650/0010-5422(2000)102[0832:PFACBI]2.0.CO;2.

Trakhtenbrot, A., Nathan, R., Perry, G., and Richardson, D.M. 2005. The importance of long-distance dispersal in biodiversity conservation. Divers. Distrib. 11: 173-181. doi:10.1111/j.13669516.2005.00156.x.

Treves, A., Naughton-Treves, L., Harper, E.K., Mladenoff, D.J., Rose, R.A., Sickley, T.A., and Wydeven, A.P. 2004. Predicting human-carnivore conflict: a spatial model derived from 25 years of data on wolf predation on livestock. Conserv. Biol. 18: 114125. doi:10.1111/j.1523-1739.2004.00189.x

Turchin, P. 1989. Population consequences of aggregative movement. J. Anim. Ecol. 58: 75-100.

Turchin, P. 1991. Translating foraging movements in heterogeneous environments into the spatial distribution of foragers. Ecology, 72: 1253-1266. doi:10.2307/1941099.

Turchin, P. 1996. Fractal analyses of animal movements: a critique. Ecology, 77: 2086-2090. doi:10.2307/2265702.

Underwood, N., Hamback, P., and Inouye, B.D. 2005. Large-scale questions and small-scale data: empirical and theoretical methods for scaling up in ecology. Oecologia, 145: 177-178. PMID: 15891848 .

Van Winkle, W. 1975. Comparison of several probabilistic homerange models. J. Wild1. Manag. 39: 118-123.

Vuilleumier, S., and Metzger, R. 2006. Animal dispersal modeling: handling landscape features and related animal choices. Ecol. Model. 190: 159-170. doi:10.1016/j.ecolmodel.2005.04.017.

Wang, G.Y., and Greenfield, M.D. 1994. Ontogeny of territoriality in the desert clicker Ligurotettix coquilletti (Orthoptera, Arcididae). J. Insect Behav. 7: 327-342. doi:10.1007/BF01989739.

Ward, M.P., and Schlossberg, S. 2004. Conspecific attraction and the conservation of territorial songbirds. Conserv. Biol. 18: 519-525. doi:10.1111/j.1523-1739.2004.00494.x.

West, P.M., and Packer, C. 2002. Sexual selection, temperature, and the lion's mane. Science (Washington, D.C.), 297: 13391343. doi:10.1126/science.1073257. PMID:12193785.

Westcott, D.A., and Graham, D.L. 2000. Patterns of movement and seed dispersal of a tropical frugivore. Oecologia, 122: 249-257. doi:10.1007/PL00008853.

White, G.C., and Garrott, R.A. 1990. Analysis of radio-tracking data. Academic Press, San Diego, Calif.

White, K.A., Lewis, M.A., and Murray, J.D. 1996. A model of wolf-pack territory formation and maintenance. J. Theor. Biol. 178: 29-43. doi: 10.1006/jtbi.1996.0004.

White, K.A.J., and Gilligan, C.A. 1998. Spatial heterogeneity in three-species, plant-parasite-hyperparasite, systems. Philos. Trans. R. Soc. Lond. B Biol. Sci. 353: 543-557.

Wiens, J.A., Stenseth, N.C., VanHorn, B., and Ims, R.A. 1993. Ecological mechanisms and landscape ecology. Oikos, 66: 369-380.

Wiens, J.A., Crist, T.O., With, K.A., and Milne, B.T. 1995. Fractal patterns of insect movement in microlandscape mosaics. Ecology, 76: 663-666. doi:10.2307/1941226.

Wiktorsson, M., Ryden, T., Nilsson, E., and Bengtsson, G. 2004. Modelling the movement of a soil insect. J. Theor. Biol. 231: 497-513. doi:10.1016/j.jtbi.2004.06.024. PMID:15488527.

Wilder, S.M., and Rypstra, A.L. 2004. Chemical cues from an introduced predator (Mantodea, Manitidae) reduce the movement and foraging of a native wolf spider (Araneae, Lycosidae) in the laboratory. Environ. Entomol. 33: 1032-1036.

Williams, J.C., ReVelle, C.S., and Levin, S.A. 2005. Spatial attributes and reserve design models: a review. Environ. Model. Assess. 10: $163-181$.

With, K.A. 1994. Ontogenetic shifts in how grasshoppers interact with landscape structure: an analysis of movement patterns. Funct. Ecol. 8: 477-485. doi:10.2307/2390072.

Wolf, L.L., Waltz, E.C., Klockowski, D., and Wakeley, K. 1997. Influences on variation in territorial tenures of male white-faced dragonflies (Leucorrhinia intacta) (Odonata: Libellulidae). J. Insect Behav. 10: 31-47.

Woodroffe, R., and Frank, L.G. 2005. Lethal control of African lions (Panthera leo): local and regional population impacts. Anim. Conserv. 8: 91-98. doi:10.1017/S1367943004001829.

Woodroffe, R., Donnelly, C.A., Johnston, W.T., Bourne, F.J., Cheeseman, C.L., Clifton-Hadley, R.S., Cox, D.R., Gettinby, G., Hewinson, R.G., LeFevre, A.M., McInerney, J.P., and Morrison, W.I. 2005. Spatial association of Myobacterium bovis infection in cattle and badgers Meles meles. J. Appl. Ecol. 42: 852862. doi:10.1111/j.1365-2664.2005.01081.x.

Worton, B.J. 1987. A review of models of home range for animal movement. Ecol. Model. 38: 277-298. doi:10.1016/03043800(87)90101-3. 